\title{
Morphology Analysis Method
}

National Cancer Institute

\section{Source}

National Cancer Institute. Morphology Analysis Method. NCI Thesaurus. Code C117625.

A means, manner of procedure, or systematic course of actions that are performed in

order to examine and interpret a morphology assessment. 